\title{
JUURNAL.RU
}

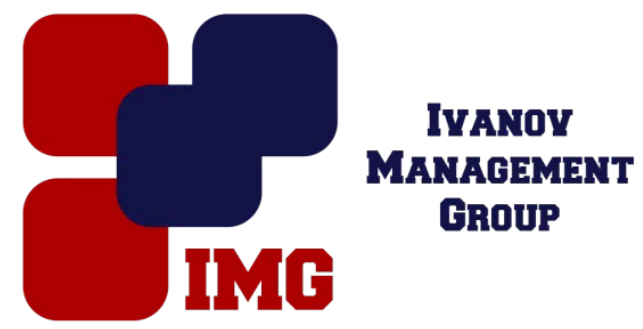

Бурлаков В.В. Саратовский сочиально-экономический институт РЭУ им Г.В. Плеханова Саратов, Россия

doi: 10.18411/lj-30-11-2016-3-02

idsp 000001:lj-30-11-2016-3-02

\section{Механизм совершенствования упрощенной системы налогообложения в рамках дифференциации налоговых ставок, в целях выполнения фискальной функции государства}

\section{Аннотация.}

В статье показаны особенности применения и пути совершенствования упрощенной системы налогообложения при взаимодействии с покупателями по налогу на добавленную стоимость.

Ключевые слова: упрощенная система налогообложения, налог на добавленную стоимость.

Упрощенная система налогообложения (УСН) популярна среди субъектов малого предпринимательства благодаря тому, что позволяет избежать целого ряда налоговых платежей в казну. Данные субъекты, согласно п.2-3 ст.346.11 НК РФ, освобождаются от уплаты налогов на прибыль и на имущество, а также не признаются плательщиками налога на добавленную стоимость.

В связи с этим, если покупатели применяют общую систему налогообложения, то им бывает невыгодно работать с поставщиком, применяющий УСН. В данной ситуации последнему приходится делать выбор: либо отказываться от данного клиента, либо нести дополнительную налоговую нагрузку в виде НДС.

Таким образом, в налоговом законодательстве необходимо дать право субъектам, применяющие УСН, право на добровольную уплату НДС. Также в целях стимулирования бизнеса необходимо ввести дифференцированные налоговые ставки по УСН. Дифференциация ставок должна быть построена по белорусскому опыту, при котором ставка по налогу при объекте -доходы должна быть следующая: $6 \%$ - для организаций и индивидуальных предпринимателей (ИП), которые не уплачивают НДС, и 4 \%, которые уплачивают НДС; при объекте налогообложения доходы, уменьшенные на величину расходов ставка налога должна составлять $15 \%$-для организаций и 
ИП, которые не уплачивают НДС, и 10 \%, которые уплачивают НДС. При этом для организаций и ИПс местом нахождения или жительства в сельских населенных пунктах при осуществлении деятельности по производству товаров, выполнению работ и оказанию услуг в этих населенных пунктах, ставки налога при упрощенной системе устанавливаются в следующих размерах: $5 \%$ - для организаций и ИП, не уплачивающих НДС, и 3 \%-для организаций и ИП, уплачивающих НДС.При этом налогоплательщик, также вправе уменьшить сумму налога на сумму страховых взносов на обязательное пенсионное страхование, обязательное социальное страхование на случай временной нетрудоспособности и в связи с материнством, обязательное медицинское страхование, а также на обязательное социальное страхование от несчастных случаев на производстве и профессиональных заболеваний, которые были уплачены в данном налоговом или отчетном периоде. При этом сумма налога или авансовых платежей по налогу не должна быть уменьшена на сумму вышеуказанных расходов более чем на 50 процентов.

В целом предлагается внести поправки в Налоговый Кодекс, с учетом вышеуказанных предложений. Данное изменение позволит дать существенную поддержку субъектам малого предпринимательства, а также в добровольном порядке быть плательщиками НДС.

\section{Литература}

1. Налоговый Кодекс Российской Федерации. - [Электронный документ]. URL:http://www.consultant.ru/popular/nalog2/

2. Налоговый Кодекс Республики Беларусь. - [Электронный документ]. URL: http://kodeksy-by.com/nalogovyj_kodeks_rb.htm 